\title{
On EST Sentence Translation Based on English and Chinese Structures: Natural Linear Expansion vs. Reversed Linear Expansion
}

\author{
Zhenghua Tan \\ Jianghan University, Wuhan, Hubei Province, China \\ Xixiang Ke \\ Wuhan Textile University, Wuhan, Hubei Province, China
}

\begin{abstract}
With the development of science, new subjects with a new technical vocabulary spurt from technology and science, and it makes translation in EST more difficult. It turns out that similarities between English and Chinese can be handled easily in translation, while differences between the two make translation in EST a hard task. The intention of this study is to analyze the formulas of the patterns between English and Chinese in thinking and explore possible advantages in translation practice.
\end{abstract}

Index Terms - EST (English of Science and Technology), natural linear expansion, reversed linear expansion, translation tactics

\section{INTRODUCTION}

With the rapid development of modern science and technology and the gradual deepening of global economic integration, English of Special Purpose will attract more and more attention from the scientific field, language researchers and governments. Written English in science and technology has become an independent subject. It covers all aspects of science and technology, including: scientific and technological academic works, scientific and technological papers and research reports, experimental reports, scientific and technological information, product patent specifications and written materials; scientific and technological exhibitions; scientific and technological talks, conferences, scientific and technological films, etc. ESP translation plays an important role in the development of science and technology all over the world. China's reform and opening up is facing an unprecedented stage of development, in order to promote the vigorous development of China's science and technology, scientific and technological English translation should arouse our attention. Compared with non-ESP, scientific English texts are characteristic by polysemy, (which the association of two or more related senses with a single linguistic form (Taylor, 1956, p.99) is ubiquitous in natural language and therefore deserves the linguists' attention), more long sentences, more passive sentences, more parts of speech, more non finite verbs, etc. According to the corpus of 1,070,000 words in Shanghai Jiaotong University, the average length of scientific English sentences is 21.4 words, and only $8.77 \%$ of short sentences with less than 7 words (including 7 words) and more than 40 words account for 6.3\% (Fang Mengzhi, 1994, p.97). Long sentences are used in ESP to describe the complicated and changeable world. The style of scientific and technological articles is simple, but the language is condensed, and the structure poly-subordinate. Therefore, it is inevitable that a large number of long and complex sentences will be produced. How to deal with the translation of long sentences has become the most concerned problem.

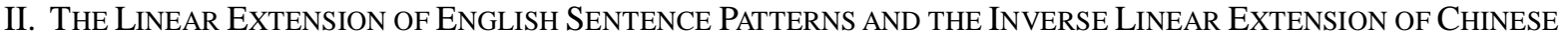 SENTENCE PATTERNS}

Translators have always attached great importance to the contrastive study of languages. The comparison between English and Chinese is the core of translation theory. Translation theories, methods and techniques between English and Chinese are based on the comparison of similarities and differences between English and Chinese. Because of the "similarity", we can translate each other; with the "difference", we have different methods and techniques. Yan Fu had made comments on English sentence structure: "in Western sentences, most of the names and things are interpreted with the help of examples. ..., in Western grammar, there are sentences with two or three words or more than one hundred of words in a sentence. " (Yan Fu, Evolution and Ethics, Translation Illustration, 1984,p.6) Lu Shuxiang, a linguist, once said, "only by comparison can we see the common and special points of various language expressions. (Lu Shuxiang, outline of Chinese grammar, Volume I, 1982, p.7) ", and stressed that, normally there are many sentences in Chinese texts, one followed another, and most of them can be taken apart or connected at random. Usual is the style of sentence pattern in Chinese with short sentences to explain the problem point by point, which makes the number of Chinese 
sentences more than of English in expressing the same content. Therefore, in translation, several short sentences in Chinese can be translated into a long English sentence connected by English related words and various phrases.

Example 1: yào zhăo dào yì zhǒng qià hăo shì yòng yú mǒu zhǒng yòng tú de gāng sī shéng, tā néng măn zú gāi yòng tú de gè fâng miàn yāo qiú, zhè chóng kè néng xìng sūi rán yǒu, dàn bì jìng hěn nán yù dào 。

While there is a possibility, there is little likelihood that an application can be found for which there is a precisely suitable wire rope - one that can satisfy every indicated requirement.

There are four sentences in Chinese, and only is a compound sentence with an adverbial clause of concession in the English translation

In Intercultural Communication, Lin Dajin points out that "extension" refers to the linear extension of basic sentence structure with the development of thinking. When English sentences are extended linearly, they are extended from left to right (LR for short), while Chinese sentences are extended inversely, from right to left (RL for short). The LR extension of English sentence makes the end of a sentence open and the beginning of a sentence contract; the RL extension of Chinese sentence makes the end of a sentence contract and the beginning of a sentence open. (Lin Dajin, 2005, p.233)"

Bi Jiwan, a scholar, Beijing Language and Culture University, interpreted that Chinese sentence parataxis and English sentence hypotaxis respectively reflect the differences of thinking modes between the overall synthesis of Chinese culture and the detailed analysis of English culture (Bi Jiwan, 2004,p34).

From the perspective of logical reasoning, Liu Miqing gives the following Chinese examples (Liu Miqing, 2006, p.267)

\begin{tabular}{|c|c|}
\hline Open pattern & extending inversely $(\mathrm{R} \mapsto \mathrm{L})$ \\
\hline Basic sentence & jǔng jǐng yǒu tiáo \\
\hline Level 1 & gàn de jǔng jǐng yǒu tiáo \\
\hline Level 2 & yí qiè gàn de jǐng jǔng yǒu tiáo \\
\hline Level 3 & tā hă yí qiè gàn de jǐng jǐng yǒu tiáo \\
\hline Level 4 & méi ziăng dào tā bă yí qiè gàn de jǐng jǐng yǒu tiáo \\
\hline Level 5 & tā péi xiăng dào tā bă yí qiè gàn de jǐng jĭng yǒu tiáo \\
\hline Level 6 & tā shuì tā méi xiăng dào tā bă yí qiè gàn de jǐng jǐng yǒu tiáo \\
\hline
\end{tabular}

In terms of the contents reflected in English sentences, it is generally from less important to important, from specific to general, which reflects the follow-up rule of sentence structure with a beginning stated shortly and a detailed ending. On the contrary, Chinese is LR expansion mechanism with a detailed beginning and an ending stated shortly.

Taking the unit of translation as an example, it is necessary to explain the unit of translation before giving examples. In Language and Translation, Balhudarov, a linguist of the former Soviet Union, defined translation unit as "the smallest (minimum) language unit in which the source language has its counterpart in the target language (Dictionary of translatology, 2004,p.19)". Vinayand Darbelnet believed that the translation unit must be the smallest part in translation. Fang Mengzhi takes it as a translation unit - a language fragment that must be considered in the whole translation process (Fang Mengzhi, 2004,p.19).

A sense group is the content of phonetics. As a language unit, it is whole in conveying feelings and meanings to others. The division of sense group is the correct expression of ideas, otherwise there will be ambiguity and misunderstanding. In written language, the division of meaning group must be judged by the reader himself. Usually, sense group is composed of several words. It can be a phrase, a clause phrase, a clause, etc. sense group may also be a word, but isolated words cannot be equated with sense group. The recognition of sense group is very important in understanding of sentence meaning and the text in translating.

The division of sense group should consider both grammatical structure and semantics. The division of grammatical structure is consistent with the division of semantic. Sense group could be thought as translation unit.

The following examples are translated by words and phrases according to the principle of translation unit.

Example 2:

a. Tom studies.

(1)

b. Tom studies hard.

c. Tom studies very hard.

(3)

d. Tom studies_very hard in the aluminum and nodular cast iron industries. 
e. Tom studies very hard in the aluminum and nodular cast iron industries every day.

f. Tom studies very hard in the aluminum and nodular cast iron industries everyday in the laboratory.

g. Tom studies very hard in the aluminum and nodular cast iron industries everyday in the laboratory of Wuhan.

Tom studies very hard in the aluminum and nodular cast iron industries in the laboratory of Wuhan .
(1) (2) (3) (4)

(1) -(7) The underlined parts are the supplementary contents of the sentences (the same below). The English sentence structures above extend from left to right with the development of thinking.

The following Chinese sentences are the corresponding Chinese translations.

tāng mǔ yán jiū $。$ A.

tāng mǔ kè kǔ yán jiū

tāng mŭ yán jiū hěn kè kǔ

tāng mǔ zài lǘ gōng yè hé qiú mò zhù tiě gōng yè fāng miàn yán jiū hěn kè kǔ

tāng mǔ měi tiān zài lư̆ gōng yè hé qiú mò zhù tiě gōng yè fāng miàn yán jiū hěn kè kǔ

tāng mǔ měi tiān zài shí yàn shì zài lư̆ gōng yè hé qiú mò zhù tiě gōng yè fāng miàn yán jiū hěn kè kǔ。 $F$.

tāng mǔ měi tiān zài wǔ hàn de shí yàn shì zài lü gōng yè hé qiú mò zhù tiě gōng yè fāng miàn yán jiū hěn kè kǔ 。G.

The comparison between English and Chinese word orders is as follows:

tāng mǔ (1) měi tiān (7) zài wŭ hàn (6) de shí yàn shì (5) zài lü gōng yè hé qiú mò zhù tiě gōng yè fâng miàn (4) yán jiū hěn (3) kè kŭ (2)。

English Word order(1) (2) (3) (4) (5) (6) (7), Chinese Word order(1) (7) (6) (5) (4) (3) (2). The main sentences ( $\mathrm{S}+\mathrm{V}+\mathrm{O})$ are the same, but the orders of modifiers are opposite to each other.

With the development of thinking, the above basic sentence structure shows an inverse linear extension.

In order to demonstrate the nature of thinking patterns between Chinese and English, more examples are as following .

Example 3:

a. All the materials are collected.

b. All the materials are collected for the research..

(2)

c. All the materials are collected for the research. project

d. All the materials are collected for the research project on pollution.

(4)

e. All the materials are collected for the research project on pollution in our college.

All the materials are collected for the research project on pollution in our college.
(1)
(2)
(3)
(4)
(5)

In the same way, the above basic sentence structure extends along the line with the development of thinking. The following is the Chinese translation of each corresponding sentence. suǒ yǒu de cái liào dōu shōu jí qǔ lái le. a.

suǒ yǒu yòng yú yán jiū dōu shōu jí qǐ lái le. b.

suǒ yǒu yòng yú yán jiū xiàng mù de cái liào dōu shōu jí qǐ lái le. c.

(3)

suǒ yǒu yòng yú wū răn yán jiū xiàng mù de cái liào dōu shōu jí qǐ lái le. d.

wǒ men xué yuàn suǒ yǒu yòng yú wū răn yán jiū xiàng mù de cái liào dōu shōu jí qǔ lái le. e.

(5)

The comparison between English and Chinese sentence order is as follows: 
wǒ men xué yuàn suǒ yǒu yòng yú wū răn yán jiū xiàng mù de cái liào dōu shōu jí qũ lái le.

(4) (3)

(1)

(2)

English Word order(1) (2) (3) (4) (5), and Chinese Word order(5) (4) (3) (1) (2)。The main sentences $(\mathrm{S}+\mathrm{V}+\mathrm{O})$ are the same, but the orders of modifiers are opposite to each other. With the development of thinking, the above basic sentence structure shows an inverse linear extension.

The following is an example of taking sentences as translation units. Because the sentence is too long, it will be operated differently on the format.

Example 4:

a. It now seems likely that the time will soon come.

(1)

b. It now seems likely that the time will soon come. if, indeed it has not yet arrived.

(2)

c. It now seems likely that the time will soon come. if , indeed it has not yet arrived when coal-burning locatives will no longer be manufactured.

(3)

d. It now seems likely that the time will soon come. if, indeed it has not yet arrived when coal-burning locatives will no longer be manufactured though they will continue to be used for many years.

(4)

It now seems likely that the time will soon come. if, indeed it has not yet arrived when

(1) (2) (3)

coal-burning locatives will no longer be manufactured though they will continue to be used

for many years.

Similarly, with the development of thinking, the above basic sentence structure presents a linear extension. The following is the Chinese translation of each corresponding sentence.

a. xiàn zài kàn lái , bú jiǔ kě néng chū xiàn nà yàng de shí dài (1) 。

b. xiàn zài kàn lái , jí shǐ nà yàng de shí dài xiàn zài shàng wèi lái dào (2), (dàn) bú jiǔ de jiāng lái kě néng huì chū xiàn 。

c. xiàn zài kàn lái , jí shǐ nà yàng de shí dài jí rán méi de jī chē jiāng bú zài shēng chăn le (3) De shí dài , xiàn zài shàng wèi lái dào , (dàn ) bú jiǔ de jiāng lái kě néng huì chū xiàn 。

d. xiàn zài kàn lái , jí shǐ nà yàng de shí dài jí rán méi de jī chē jiāng bú zài shēng chăn le , dàn zhè xiē rán méi jī chēe jiāng réng rán shǐ yòng hěn duō nián (4) de shí dài , xiàn zài shàng wèi lái dào , (dàn ) bú jiǔ de jiāng lái kě néng huì chū xiàn 。

xiàn zài kàn lái , jí shǐ nà yàng de shí dài jí rán méi de jī chē jiāng bú zài shēng chăn le ,

dàn zhè xiē rán méi jī chē jiāng réng rán shǐ yòng hěn duō nián de shí dài , xiàn zài

(5)

shàng wèi lái dào,$\quad$ (dàn ） bú jiǔ de jiāng lái kě néng huì chū xiàn

The order of English sentence is (1) (2) (3) (4) (5) and that of Chinese sentence is(1) (4) (5) (3) (2). The order of the main part of the sentence $(\mathrm{S}+\mathrm{V}+\mathrm{O})$ is the same, but the order of the modifier is slightly different. With the development of thinking, the above sentence structure shows an inverse linear extension.

Whether the translation unit is words, phrases or sentences, they presents that sentences ( English or Chinese sentence patterns) are the most basic sentence pattern. The orders of their main parts $(\mathrm{S}+\mathrm{V}+\mathrm{O})$ indicate the similarity in English and Chinese, but the word order of the modifier is opposite to each other. So we can get some inspiration.

\section{TRANSLATION STRATEGIES AND STEPS IN EST}

English for science and technology is a language used to state what happens or appears in nature and science and technology circles, and describe its laws, characteristics and processes. It has features of objectivity and accuracy, logic, rigor, long sentences and complex structures. From the perspective of syntax, why it is difficult to make long sentences is that there are many modifiers, restrictions and additional elements, resulting in the separation structure (the modifier is separated from the modified element). According to the rule of linear extension in English sentences, it is linear extension while in Chinese it is inverse linear extension, and the main parts of English and Chinese sentences (subject + predicate + object) are similar. To deal with long and difficult sentences, we can take the following steps and methods in translating.

A. Main-sentence Extraction

In EST, no matter how long a sentence is, it always has the main part of a sentence, that is, subject and predicate. To 
find out the main part of a sentence is to grasp the gist of the sentence. In the application of trunk extraction, this also serves as the first step of translating long sentences.

Example 5:

Gas generating components, capable of quickly producing a large quantity of solids-free nontoxic gases useful as propellants in Halon replacement fire suppression systems consist of a double-based castable propellant formulated from a major amount of ammonium nitrate, a minor amount of nitrocellulose, one or more high-energy nitrate ester plasticizer, a thermal scavenger, and a combustion rate modification.

This is a sentence with about 60 English words, "capable of quickly producing a large quantity of solids-free nontoxic gases" and "useful as propellants in Halon replacement fire suppression systems", they are adjective phrases used as attributives. Therefore, the subject is "Gas generating components," The verbs that can be used as predicates in long sentences are "consist of" phrase and "formulated from". But if you look at it carefully, "formulated from a major amount of ammonium nitrate, a minor amount of nitrocellulose, one or more high-energy nitrate ester plasticizer, a thermal scavenger, and a combustion rate modification." is a past participle phrase. It's an attribute in the sentence. So the predicate is "consist of". The main structure of the sentence is "Gas generating components consist of...".

According to the same order of main parts (subject + predicate + object) of English and Chinese sentences. Accordingly, the Chinese structure is "shēng chéng qì tǐ chéng fèn shì yóu ...zǔ chéng " Therefore, the translation is as follows:

zuò wéi hā lóng miè huǒ qì tì dài xì tǒng tuī jìn jì de shēng chéng qì tǐ chéng fèn , （yīng shì ） yǒu zhù yú kuài sù chăn shēng dà liàng wú gù tǐ cán zhā hé wú dú de qì tǐ , yóu cóng rán shāo lǜ xiū zhèng 、 jiăn rè zhuāng zhì 、 dà liàng xiāo suān ăn 、wēi liàng de xiāo huà xiān wéi 、yī zhǒng huò shù zhǒng gāo néng xiāo suān zhī kě sù jì děng xiàng guān zhū yīn sù shè xiăng ér lái de kě jiāo zhù shuāng jī tuī jìn jì zǔ chéng 。

Example 6:

Victory Garden, a collection of 75 essays ranging from general topics such as fertilizers and crop yield to detailed information on all the standard garden vegetables and 60 species of houseplants, is now part of Compuserve's thousands of informational categories, according to Ted Batutis, a computer consultant with a doctorate in vegetable crops.

First, analyze the sentence, "Victory Garden", which may be part of the subject."a collection of 75 essays...",it may also be part of the subject. However, through the interpretation, we can see that the latter is the explanation of the former. Therefore, the subject is "Victory Garden". Look at the predicate part again. The predicate part of this sentence is very obvious. There is only one verb form, namely, "is part of ...", the composition of the predicative part .According to the same order of main parts (subject + predicate + object) of English and Chinese sentences. The Chinese sentence is “ 《shèng lì yuán pǔ 》, xiàn zài shì Compuserve jǐ qiān zhǒng xìn xī fèn lèi zhōng de yī bù fèn 。”

The Chinese whole sentence is:

jù shū cài zuò wù xué bó shì 、 jì suàn jī gù wèn Ted Batutisshuō , shōu lù 75 piān lùn wén , nèi róng hán gài cóng féi liào hé zuò wù chăn liàng děng pǔ biàn xìng wèn tí , zài dào yǒu guān gè zhǒng biāo zhǔn de yuán pǔ shū cài hé 60 zhǒng shì nèi zuò wù de xiáng xì zī liào de 《shèng lì yuán pǔ 》,xiàn zài shì Compuservejǐ qiān zhǒng xìn xī fèn lèi zhōng de yī bù fèn 。

\section{B. Translation Methods of Branches Based on English Linear Extension and Chinese Inverse Linear Extension}

According to the rule that English sentence structure extends from left to right with the development of thinking, and Chinese sentence structure extends from right to left. Split multiple translation units one by one, whether they are words, phrases, or sentences. It also serves as the second step in translating EST sentences.

Take example 5 as an example:

Gas generating components, capable of quickly producing a large quantity of solids-free nontoxic gases useful as propellants in Halon replacement fire suppression systems consist of a double-based castable propellant formulated from a major amount of ammonium nitrate, a minor amount of nitrocellulose, one or more high-energy nitrate ester plasticizer, a thermal scavenger, and a combustion rate modification.

Split by phrase:

(1) Gas generating components

(2) capable of quickly producing a large quantity of solids-free nontoxic gases

(3) useful as propellants

(4) in Halon replacement fire suppression systems

(5) consist of a double-based castable propellant

(6)formulated from a major amount of ammonium nitrate, a minor amount of nitrocellulose, one or more high-energy nitrate ester plasticizer, a thermal scavenger, and a combustion rate modification.

Corresponding Chinese Translation:

(1) shēng chéng qì tǐ chéng fèn

(2) kuài sù chăn shēng dà liàng wú gù tǐ cán zhā hé wú dú de qì tǐ

(3) zuò wéi tuî jìn jì (shì ) yǒu bāng zhù de 
(4) zài hā lóng miè huǒ qì tì dài xì tǒng zhōng

(5) yóu kě jiāo zhù shuāng jī tuī jìn jì zǔ chéng

(6) yóu cóng rán shāo lü xiū zhèng 、 jiăn rè zhuāng zhì 、 dà liàng xiāo suān ăn 、wēi liàng de xiāo huà xiān wéi 、 yī zhǒng huò shù zhǒng gāo néng xiāo suān zhī kě sù jì děng xiàng guān zhū yīn sù shè xiăng ér lái de

On the basis of completing the first step of the trunk extraction method. The order of the main part (subject + predicate + object) is the same in both English and Chinese, after completing the first step of the trunk extraction method,the sentence can be divided into some parts according to the rule of linear extension of English thinking and inverse linear extension of Chinese thinking, and reorganize the EST sentence:

Main structure: shēng chéng qì tǐ chéng fèn shì yóu ...zǔ chéng 。

zuò wéi hā lóng miè huǒ qì tì dài xì tǒng tuī jìn jì de shēng chéng qì tǐ chéng fèn ,

(yīng shì ) yǒu zhù yú kuài sù chăn shēng dà liàng wú gù tǐ cán zhā hé wú dú de qì tǐ ,

yóu cóng rán shāo lǜ xiū zhèng 、 jiăn rè zhuāng zhì 、 dà liàng xiāo suān ăn 、 wēi liàng de xi

(6)

āo huà xiān wéi 、 ȳi zhǒng huò shù zhǒng gāo néng xiāo suān zhī kě sù jì děng xiàng guān

zhū yīn sù shè xiăng ér lái de kě jiāo zhù shuāng jī tuī jìn jì zǔ chéng 。

Similarly, example 6 can be split as follows:

Victory Garden, a collection of 75 essays ranging from general topics such as fertilizers and crop yield to detailed information on all the standard garden vegetables and 60 species of houseplants, is now part of Compuserve's thousands of informational categories, according to Ted Batutis, a computer consultant with a doctorate in vegetable crops.

Split by phrase:

(1) Victory Garden

(2) a collection of 75 essays

(3) ranging from general topics such as fertilizers and crop yield to detailed information on all the standard garden vegetables

(4) 60 species of houseplants

(5) part of Compuserve's thousands of informational categories

(6) according to Ted Batutis

(7) a computer consultant with a doctorate in vegetable crops

Corresponding Chinese Translation:

(1) 《shèng lì yuán pǔ》

(2) shōu lù 75 piān lùn wén de zá zhì

(3) nèi róng hán gài yǒu cóng féi liào hé zuò wù chăn liàng děng pǔ biàn xìng wèn tí zài dào yǒu guān gè zhǒng biāo zhŭn yuán pǔ shū cài de xiáng xì shuō míng

(4) (nèi róng hán gài ) 60zhǒng shì nèi zuò wù

(5) Compuservejǐ qiān zhǒng xìn xī fèn lèi zhōng de yī bù fèn

(6) jù Ted Batutis

(7) shū cài zuò wù xué bó shì 、 jì suàn jī gù wèn

After completing the first step of the trunk extraction method,the sentence can be divided into different parts according to the rule of linear extension of English thinking and inverse linear extension of Chinese thinking, and reorganize the EST sentence:

The Chinese main sentence: 《shèng lì yuán pǔ 》,xiàn zài shì Compuserve jǐ qiān zhǒng xìn xī fèn lèi zhōng de yī bù fèn 。

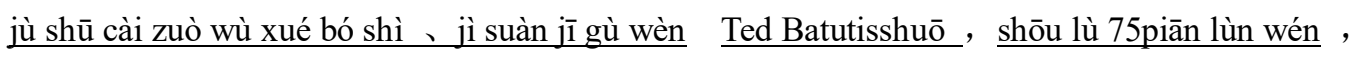

nèi róng hán gài cóng féi liào hé zuò wù chăn liàng děng pǔ biàn xìng wèn tí , zài dào yǒu guān gè zhǒng biāo zhǔn (3)

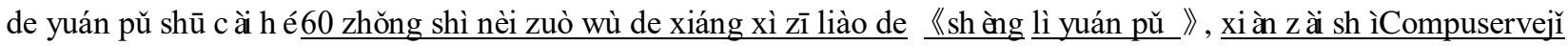
(4)

qiān zhǒng xìn xī fèn lèi zhōng de yī bù fèn

From the above analysis, we can conclude that: Sentence length, there are many long sentences in English and short sentences in Chinese. In Chinese, on the contrary, meaning is expressed directly through words, and different meanings are often expressed through different short sentences; Sentence structure differences: English is more subordinate than Chinese. English sentences use long modifiers in simple sentences to make sentences longer, and use clauses to make 
sentences more complex, which are often connected with the main sentence or other clauses through the leading words of clauses; Chinese always like using short sentences, and the expression structure is relatively loose, and when English clauses are translated into Chinese, they often become some clauses. Based on those, these steps are suggestions in translating EST.

\section{CONCLUSION}

The linguists in China have done pioneering work in comparing English and Chinese. With the rapid development of science and technology, a variety of new disciplines and fields emerge as the times go by, and a large number of new scientific and technological words come into being, which makes the translation of scientific and technological English literature more and more difficult. Translation practice has proved that the similarities between English and Chinese are generally easier to transfer between the two languages, while the differences between English and Chinese are often the difficulties in translation. Therefore, we try to explore the nature of the translation skills of scientific and technological English literature. Once we find out the differences between English and Chinese and the regularity of their expression, the problem will be solved. It not only accelerates the speed of translation, but also improves the quality of translation, and constantly improves the translation level of scientific English documents.

\section{REFERENCES}

[1] Bi Jiwan. (2001). The role of the comparison of Chinese and foreign modes of thinking in Chinese teaching for foreigners. Foreign language teaching, 3:17-21.

[2] Chen Ding'an. (2007). Comparison and translation of English and Chinese sentence structures.

[3] Fang Mengzhi. (1994). English-Chinese translation practice and skills. Tianjin: Tianjin Science and Technology Translation Publishing Company.

[4] Fang Mengzhi. (2004). Dictionary of translatology. Shanghai: Shanghai Foreign Language Education Press.

[5] Guo Huili. (2008). Chemical English translation skills. Beijing: China Science and technology translation, 3: 13-15.

[6] J. Herbert. (1980). The structure of scientific English. Beijing: Metallurgical Industry Press. Beijing: China International Translation Publishing Company.

[7] John Taylor. (2007). Ten Lectures on Applied Cognitive Linguistics. Beijing: foreign language teaching and Research Press.

[8] Lin Dajin. (2005). Intercultural communication. Fuzhou: Theory and practice. Fujian people's publishing house.

[9] Liu Miqing. (2006). New Chinese English comparison and translation. Beijing: China International Translation Publishing Company.

[10] Lu Shuxiang. (1982). Outline of Chinese grammar. Beijing: Commercial Press.

[11] Mao Ronggui. (1999). 111 lectures on translation skills. Shanghai: Shanghai Jiaotong University Press.

[12] Shen Xiaolong. (1997). Chinese sentence pattern culture. Shanghai: Fudan University Press.

[13] Xie Tianzhen. (2000). Translation theory construction and cultural perspective. Shanghai: Shanghai Foreign Language Education Press.

[14] Xie Tianzhen. (2003). A new perspective of translation theory. Qingdao: Qingdao press.

[15] Yan Fu. (1984). Anthology of translation studies. Beijing: foreign language teaching and Research Press.

[16] Yan Qingjia, Yan Wenpei. (1992). Translation methods of scientific English. Beijing: Metallurgical Industry Press.

[17] Zheng Shengtao. (2008). Bracket translation of long sentences in English for science and technology. China Science and technology translation, 2:42-46.

[18] Zou Renjie. (1988). Chinese English technology translation skills. Shanghai: Tongji University Press.

Zhenghua Tan was born in Hubei Province, China in 1966. He received Master's degree in linguistics from Central China University of Science \& Technology, China in 2004.

$\mathrm{He}$ is currently an associate professor in the School of Foreign Languages, Jianghan University, Wuhan, China. His research interests include translation theory and practice.

Xixiang Ke was born in Hubei Province, China in 1975. She received Master's degree in linguistics from Central China University of Science \& Technology, China in 2006.

She is currently an associate professor in the School of Foreign Languages, Wuhan Textile University, Wuhan, China. Her research interests include translation theory and practice. 